\section{THE RUSSIAN BASE OF OPERATIONS AGAINST INDIA.}

Aт Baku, on the Caspian Sea, there stands an old temple, where for centuries a beacon has been kept continually burning by the fire-worshippers of India and Persia. 'The priests in the olden time declared that the light was supernatural, the gift of the god of fire. Modern science shows that the supply comes from gas-wells. On one side of this temple are derricks and oil-wells; on the other side, a great stone embankment stretching for over a mile along the seacoast, several hundred steam and sailing vessels, long trains of railroad-cars loading with oil, and a population of fifty thousand where ten years ago were less than fifteen thousand. The Parsee, tending his eternal fire, is the emblem of the past : the Russian, with his oil-wells and embankments, his railroads and steamboats, is the emblem of the present.

From Baku, steamers run north, through the Caspian Sea, to Astrakhan, near the mouth of the Volga; thence up the Volga and Kama to Perm ( 25 miles by rail from Ekaterinburg in Siberia, whence come the best iron rails and manufactures of iron and steel), up the Volga and the Olga to the neighborhood of Moscow, up the Volga to Rybinsk, whence a canal continues the navigation to the Baltic. On these waters the cotton from Khiva and Bokhara, the oil from the Caspian, the wool from Astrakhan, and the grain from the lower Volga, are borne to the Baltic and the North seas, while material and supplies from all parts of Europe are brought as return cargo. Some of the steamers plying on the Volga resemble our Mississippi steamers, and are as large and commodious: others, two hundred feet long, are fitted with cisterns, into which the oil flows, through pipes from reservoirs at the refineries, at the rate of from a hundred to two hundred tons an hour. Kerosene from Baku has nearly superseded the American oil in Russia, and now competes with it in Berlin and Vienna. From Baku the railroad runs west (561 miles in thirty-six hours), along the foot of the Caucasus Mountains, through Tiflis, to Poti

The map published in the present number, to accompany this and other articles, is based upon one issued from the office of the superintendent of the great trigonometric survey of India. The original was mapped on the bases of the surveys made by British and Russian officers up to 1881, and was published in Dehra Dun in September, 1881. As slightly reduced here, it represent. the territory on a scale of an inch to forty miles. The uppe broken red line represents the boundary of the territory in dispute as given on the map of which this is the copy; and it also appears in precisely the same place, in the latest reduction of the Russian staff map obtainable in St. Petersburg two years ago; but the lower broken red line indicates what is supposed to be the extreme Russian claim, and does not appear on the original from which the map is taken. and Batum on the Black Sea. From these seaports, Russian steamers, the best on the Mediterranean and Black seas, make quick trips to Sebastopol and Odessa ; and railroads connect these cities with all parts of Russia, easter'n and western Europe. Directly across from Baku (sixteen hour's by steamer), on the other side of the Caspian Sea, the transCaspian railroad commences, runs to Askabad (280 miles), and is being rapidly extended towards Sarakhs $(185$ miles from the present terminus). From Sarakhs to Herat is about 200 miles up the river Hari Rud, or Tajand. The construction of a railroad would be more difficult between these places than between Sarakhs and the Caspian Sea; though, as it must follow the line of the river, there would be no obstacles that cannot be easily surmounted.

Sibi is the present terminus of the Indian railways, though the English government is extending the line 135 miles to Quetta, 470 miles from Herat by the way of Kandahar. This route crosses many rivers and mountain ranges, and will be a difficult and expensive road to build. It requires twice as long for the transit of men and supplies from Sibi to Herat as from Herat to Baku, though the distance is but little more.

The Caspian line is the most feasible and shortest route for a railroad from Europe to India.

From London to Berlin Hours.

Thence by Breslau and $\dot{0} \dot{b} \cdot \dot{0} \dot{0} \cdot \dot{*} \cdot 2+$

By steamer to Batum .. . . . . . . . . 48

By rail to Baku . . . . . . . . . . . . 24

By steamer across the Caspian . . . . . . . 16

By rail to Askabad . . . . . . . . . . . 12

From London to Askabad ${ }^{1}$ (7 days) . . . 172 Thence to India, 1,000 miles, in . . . . . . 40

Nine days' running time, if the railroad were in operation, from London to India . . . 212

While from London to Herat, by the Suez Canal and India, is nearly three times as long.

The trans-Caspian railroad, from the Caspian to Sarakhs, runs in a south-easterly direction, at the foot of a long range of mountains separating Turkestan from Persia. Sinall streams, every few miles, run down the sides of the mountains into the valley, and are soon lost in the sands of the desert. Wherever these streams appear, there are fertile oases. This desert extends from the foot of these mountains, north-east to the River Oxus, about 500 miles at the Caspian Sea, and 300 miles at

${ }^{1}$ Here ends the present line of railroad. 


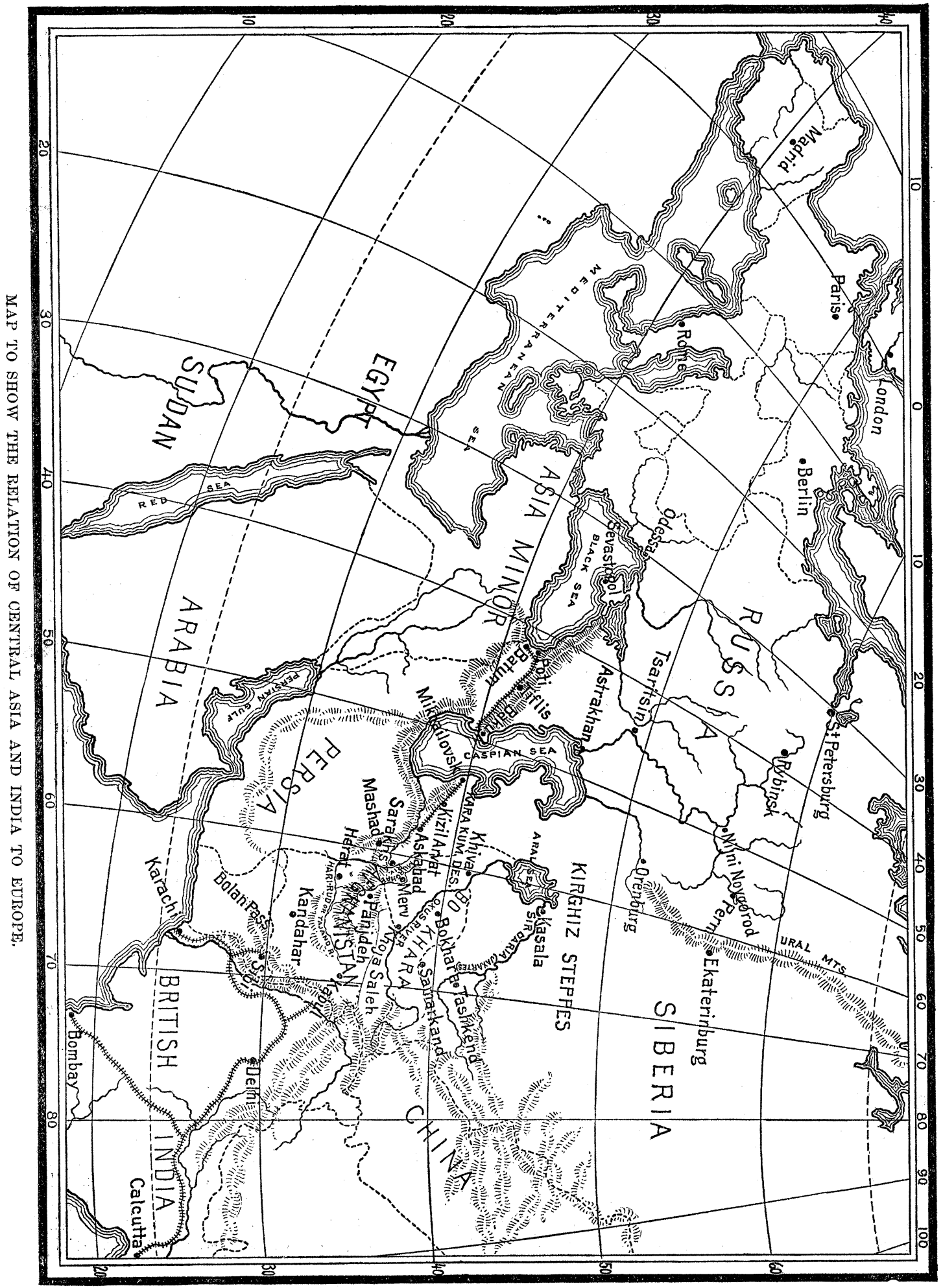


Sarakhs. The rivers Tajand and Murgh-áb run from the mountains of Afghan into the south-western part of the desert, nearly parallel to the Oxus, until they are absorbed by the sands of the desert. The old channels through which they once ran into the Oxus can still be traced. Formerly this desert was a rich, fertile land, cultivated by irrigation, inhabited by a vast population, where for hundreds of miles " a nightingale could fly from branch to branch of the fruit-trees, and a cat walk from wall to wall and housetop to housetop." The monuments of the old cities are frequently seen by the traveller, half buried in the sand. Now the desert is traversed only by a few wandering horsemen, or an occasional shepherd with his flocks, and is sparsely inhabited on the few oases that have been preserved.

The great cities of Turkestan are Khiva on the Oxus; Bokhara, Samarkand, and Tashkend, north of it. The former route from Russia to these cities was by rail to Orenburg on the dividing-line between Europe and Asia (and the termination of the Russian railways), thence across the desert to Kasala on the Aral Sea, then by steamer up Sir Daria (the Jaxartes) or through the Aral Sea, and up the Amu Daria (the Oxus). These rivers are navigable only at their flood, and are very dangerous even for the smallest steamers. At other seasons the route is all the way across the desert. It is 900 miles from Orenburg to Kliva, 1,100 to Bokhara, and 1,225 miles to Samarkand, and takes fifty days for the caravans to go from Orenburg to Samarkand. A few years ago this route became for a time impassable, owing to frequent incursions of robber-bands. A trader from Khiva, bound to the great fair at Nijni Novgorod, was compelled to find some other route : he crossed the desert from Khiva to the Caspian Sea (500 miles), and found it easier and quicker than from Khiva to Orenburg. Here he took the Baku steamer up the Volga to Nijni Novgorod. Other caravans followed. The Russian armies, with their supplies, which had been sent by the way of Orenburg and Kasala, were sent by the Caspian route. When the Caspian railway is extended to Sarakhs, Bokhara will be within 300 miles, and Merv less than 100 miles, from the line of the road.

The discovery of oil at Baku has built that city, and made it the entrepot of all kinds of stores; has opened a railroad from Tiflis to Baku, and created a fleet of steamers plying on the Caspian and Volga; has turned the course of the Asiatic trade from Orenburg to the Caspian, and transferred the government of Asia from 'Turkestan to 'Tiflis ; has led to the opening of the Caspian and the construction of the trans-Caspian railroad; and has brought Merv, Herat, and India forty days nearer St. Petersburg than they were six years ago, reducing, by fully three-fourths, the cost of transportation of men and supplies, and opening a new era for Asia. The great saving in time in the cost of transportation of men, munitions of war, and stores, will amply pay the interest on the cost of the road, and its operating-expenses.

England and Russia could easily unite in the construction and operation of the Caspian road. They have a common interest, - the shortest way to their respective dominions. The cause which threatens conflict between these two powers on the borders of Afghanistan should be the occasion of peace. England wants on the west of India a strong and permanent power, such as Afghanistan can never be, although supported by constant subsidies, supplemented, when these failed, by an armed force. Russia, on her eastern boundary, also needs a strong and permanent power to restrain the wandering tribes from despoiling her territory.

The English complain that the policy of Russia for a hundred years has been to extend her dominions in every quarter, and in proof point to the continual expansion of her territory. Scarcely a century ago the eastern and southern boundaries of Russia followed the Volga down to Tsaritsin, about three hundred miles from the Caspian, then crossed to the Don, following that river to the Black Sea. Since then the Russian army has crossed the Caucasus, conquered the whole of Circassia and a portion of Persia and 'Turkey in Asia, and pushed its southern boundary two hundred miles south of the Caucasian Mountains. It has pushed its south-eastern boundary down to the Caspian, around the head and eastern shore of that sea, reaching out to the Sea of Aral, annexing Khiva, Bokhara, Turkestan, and the Kirghiz Steppes, even to the western boundary of China. Quite recently it has annexed Merv, and threatens Herat; and now, firom the Black Sea and Persia north to the Arctic Ocean, the Russian eagle is the only flag that waves.

Russia, again and again, through her leading statesmen, has assured England that she had reached her eastern limits, and as often have these assurances been contradicted by further conquests in the east. The English naturally regard these assertions as promises made only to deceive, and to be broken as soon as the hostile feeling of Great Britain, aroused by 
such conquests, has been quieted. May not, however, the intentions of the Russians be honest, and the cause of this apparent breach of faith be easily explained?

All the country from the Don and the Volga east to China and India, and from the Caucasus south to the Persian Gulf, and southwest to the Mediterranean, has been occupied on the one side by wandering tribes without fixed habitation or permanent government, marauders, slave-dealers, and vagabonds; while on the south and south-west the countries have been and are ruled by the Persians and Turks, whose dominion is a constant curse to the people over whom they rule, the tax-gatherers being the only evidence to them of a government.

Wherever the Russians have established a new eastern boundary, settlements have sprung up. These settlements must be protected from pillage by the wandering chiefs. It was not sufficient to chastise the marauders and return within the boundary, as the return was regarded as a retreat, and proof of weakness. Experience has taught the Russians, that, in order to keep peace, these tribes must be brought under Russian rule : thus, by force of circumstances, they have been compelled to extend their territory from time to time. The conquered countries have been governed by the ablest generals of Russia, a Kaufmann and a Skobeleff. Their authority was almost despotic ; and frequently kingdoms have been annexed before either Russia or Europe knew of the forward movement. When once annexed, the government could not recall its army, or refrain from governing the conquered country.

The Russians are only carrying out the policy adopted by the English in India a hundred and fifty years ago. Her rule then extended only over a few tribes. Lord Clive and Warren Hastings were forced to extend her dominions north to the Himalayan Mountains, and south to the Pacific Ocean, until the whole peninsula of India became her empire; which, though not as extensive territorially as Russia, yet in wealth and population far exceeds that of Russia in Asia.

Wherever the Russian has gone, there he has carried law and government, settled habitations, and civilization. 'Though we may regard the civilization as crude and the government as bad, yet it is a vast improvement over the former misrule. Robbery has been stopped, slavery abolished, and the permanent cultivation of the land begun. With the exception of one or two tribes in the Caucasus, there is not a single nation or tribe that does not greatly prefer the rule of Russia to the misrule of their former chiefs.

After the capture of Merv by the Russians, Afghan was the only country that separated the Russian dominions from the English empire. The western boundary of Afghan then became a subject of great importance to England. The capture of Merv was acquiesced in by Great Britain on the agreement with Russia that a joint commission should be appointed to "delimit the Afghan frontier from Khoja Saleh on the Oxus, to Sarakhs " on the Hari-Rud, or 'Tajand, - a distance of about three hundred miles.

The Russians claim that this boundary-line runs south of Panj Deh, crossing the Hari-Rud or Tajand about fifty miles below Herat, following a range of mountains that runs, or at least was supposed to run, from the Oxus River to the Tajand.

The English claim that it crosses the river about two hundred miles below Herat. The line has never been fixed. In the article on Afghanistan, in the last edition of the Encyclopaedia Britannica, two boundaries are given. The first crosses the river about seventy miles below Herat, and follows closely the line now claimed by Russia. It says, "The halfindependent Hazara tribes stretch across the branches of the river of Herat, and down into the Oxus basin, so that it is difficult here to assign a boundary.",

On two maps in my French atlas, the boundary-line crosses the Tajand at different places. On the large map of the Messrs. Johnson, published in Edinburgh, two boundaries are also given; though the outer one, now claimed by England, has greater prominence. At one time the line was described as running along a high mountain range which passed south of the Murgh-áb River, and between that river and the Tajand, - substantially the line now. claimed by Russia; but when it was discovered that this range existed only on the maps and in accounts of early travellers, and that there was no mountain barrier, the boundaryline was mored farther west. ${ }^{1}$ Until recently, the western boundary had never been a subject of interest to the amir of Afghan or to the English or Russian governments. The land within the disputed territory is of little value. The population is sparse, with few affiliations with the Afghans. The people belong to a different race, having features of the Mongol type, speaking a different language, and pay-

\footnotetext{
1 The London Times says, "The limits have changed according to the character and military resources of the chiefs ruling at Herat, Kabul, and Kandahar."
} 
ing tribute to the Afghans only when compelled by an armed force. According to the London Times, the amir of Afghan did not occupy this disputed territory until 1883 , when he received a map from the viceroy of India, with the boundary-line now claimed.

The Russians claim that the English have furnished the Afghans with maps, plans of fortifications, money to build and equip these forts, and engineers to superintend the construction, and that these acts are a breach of good faith on the part of England. The English claim that Russia has sent an armed force into the disputed territory, occupying at least two towns, and that these acts are a breach of good faith on the part of Russia.

The English policy in India has been the same as that of Russia. It was found necessary, and proved successful, to the maintenance of order; and there is every reason to believe that a similar policy will produce like results. Gardiner G. Hubbard.

\section{ROADS FROM INDIA TO CENTRAL ASIA.}

Dost Muhammad, one of the most famous amirs of Afghanistan, is reported to have said that he could not understand why the masters of the riches of India ever should have designed "occupying such a country as Kabul, where there is nothing but rocks and stones." It was a shrewd remark; and Afghanistan owes its importance, not to the fertility of its soil or to any other natural advantages, but to the fact that the great trade and military routes of central Asia lie within its borders. Afghanistan - using the word in its broadest sense, as including all the territory under the rule of the present amir - takes the form, roughly speaking, of an immense square, with sides of about six hundred miles in length. On the west a well-defined boundary separates it from Persia. To the south the dividing-line between the territories of the amir and those of the khan of Kelat, as the ruler of Baluchistan is often called in English books, is not so well marked; but, as a large portion of it runs through an uninhabitable salt desert, this is not of much importance. On the east the Suliman and other mountain ranges form a natural frontier between Afghanistan and British India. At one time this mountain barrier was supposed to be impracticable for the movement of large masses of troops. To-day it is certain that such is not the case; for, in addition to the well-known Khyber, Kuram, and Bolan passes, more than two hundred other paths cross these mountains in every direction. In fact, the barrier is no barrier at all, and would offer but little resistance to an enterprising general. It is on the north, however, that Afghanistan is most vulnerable. True, the Amu Daria or Oxus River, from its source 13,900 feet above the sea, in Lake Sir-i-Kuld, in the highland of Great Pamir, to Khoja Saleh, separates the Afghan provinces of Badakshan and Turkestan from the Russian dominions of Ferghana and Bokhara. But a river is, at best, a poor boundary, from a military point of view ; and, besides, from Khoja Saleh to the Persian frontier, on the Hari-Rud, the line, wherever run, must be purely artificial.

More unfortunate still, the Hindu Kush, with its outlying spurs - the Khor-i-Baba, Safed Kur (White Mountains), and Siah Kur (Black Mountains) - running from east to west, divides Afghanistan into two unequal parts. The territory lying north of these mountains belongs, physically speaking, to the basin of the Oxus (Aralo-Caspian basin), or, in other words, to Russian Asia. In addition, these mountains, together with their off-shoots to the south, prevent, during five months in each year, all direct communication between Kabul, the chief city of the east, and Herat, the equally important emporium of the west. The main route between these two places is through Kandahar, which thus lies at the southern apex of a nearly equilateral triangle, with sides of three hundred and three hundred and thirty-five miles. The position of these places once thoroughly grasped, there is no difficulty in understanding the base of the English operations in Afghanistan.

From Karachi (Kurrachee) on the Arabian Gulf, and near the mouth of the river Indus, a railway runs along that river by Haidarabad to Sukkur. At this point it crosses the Indus, and, passing by Multan, joins the line from Calcutta and Bombay at Lahore. The latter road runs thence by Rawal Pindi, crossing the Indus near Attock, to Peshawar at the entrance of the Khyber Pass. The last of this railwaysystem - the missing link from Multan to Lahore' - was open to traffic in 1878.

Kabul, the chief political city of Afghanistan, contains a population of between fifty and sixty thousand. It is situated on the Kabul River, not far from its confluence with the Logar, and is the converging point of the traderoutes from Afghan Turkestan, and the countries beyond the Oxus, over the difficult mountain passes, eleven and twelve thousand feet high, of the Hindu Kush; from Persia and Baluchistan by Kandahar ; and irom India by 